\title{
Assessment of plasma and tissue fibronectin EIIIB splice variant expressions measured serially using RT-PCR in a wound model of rabbits
}

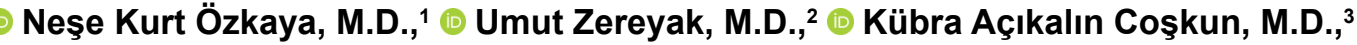 \\ (1) Yusuf Tutar, M.D., ${ }^{4}$ 을 Sarper Yılmaz, M.D. ${ }^{5}$
}

\begin{abstract}
'Department of Plastic Reconstructive and Aesthetic Surgery, Cumhuriyet University Faculty of Medicine, Sivas-Turkey ${ }^{2}$ Department of Plastic Reconstructive and Aesthetic Surgery, Private Medicana Hospital, Sivas-Turkey

${ }^{3}$ Research Center, Cumhuriyet University Faculty of Medicine, Sivas-Turkey

${ }^{4}$ Department of Biochemistry, Basic Pharmaceutical Sciences, University of Health Sciences Faculty of Pharmacy, and Molecular Medicine Program, İstanbul-Turkey

${ }^{5}$ Department of Plastic Reconstructive and Aesthetic Surgery, Ufuk University Faculty of Medicine, Ankara-Turkey
\end{abstract}

\begin{abstract}
BACKGROUND: Fibronectin (FN) is an indispensable part of the extracellular matrix. During regeneration or wound healing, the plasma form of $\mathrm{FN}$ is incorporated into the fibrin clots to form a temporary fibrin-FN matrix, and also locally synthesized cellular FN migrates to the clot to regenerate the injured tissue. We aimed to examine wound tissue FN EllIB and plasma FN EllIB expression levels in an experimental wound healing model in rabbits.
\end{abstract}

METHODS: Plasma and tissue EIIIB splice variant expressions were measured serially with RT-qPCR in a cutaneous wound model of rabbits.

RESULTS: Tissue FN expression increased as beginning on day 3 and continued to increase on days 6 and 9, reaching maximum expression at day 12 before starting to decrease. On the contrary to the tissue levels, plasma FN levels gradually decreased until day 15 when expression returned to the initial values.

CONCLUSION: The findings of the current study support that tissue EIIIB expression level increases during wound healing; and plasma EIIIB expression level decreases minimal changed. This is in contrast to reports where plasma FN provisionally helps ECM formation. Therefore, our data show an essential role of EIIIB at the tissue level in accelerating the wound healing process. The RT-qPCR method in our experimental setup can provide more accurate and precise results compared to the antibody-based methods.

Keywords: Fibronectin; plasma fibronectin ElIIB; rabbit; RT-qPCR; wound healing.

\section{INTRODUCTION}

The cutaneous wound healing process varies depending on the depth of the wound, infection status, and presence of chronic diseases that may impair skin wound healing, especially when the wound itself is found chronically. It has several consecutive biochemical steps as follows: rapid vasoconstriction and coagulation, vasodilatation and inflammation, prolif- eration, reepithelialization, differentiation, angiogenesis, and synthesis and remodeling of extracellular matrix (ECM). The whole process can be beinated, step by step process that is directed by interactions between intracell and intercellular divided into three phases: inflammatory, proliferative, and remodeling. ${ }^{[1,2]}$ This healing is a tightly coord.

Cite this article as: Kurt Özkaya N, Zereyak U, Açıkalın Coşkun K, Tutar Y, Yılmaz S. Assessment of plasma and tissue fibronectin EIIIB splice variant expressions measured serially using RT-PCR in a wound model of rabbits. Ulus Travma Acil Cerrahi Derg 2020;26:497-502.

Address for correspondence: Neşe Kurt Özkaya, M.D.

Sivas Cumhuriyet Üniversitesi Tıp Fakültesi Plastik Rekonstrüktif Estetik Cerrahi Anabilim Dalı, Sivas, Turkey

Tel: +90 346 - 2580425 E-mail: ozkayanesekurt@gmail.com

Ulus Travma Acil Cerrahi Derg 2020;26(4):497-502 DOI: 10.14744/tjtes.2020.25260 Submitted: 31.0I.2020 Accepted: 28.03 .2020 Online: I5.06.2020

Copyright 2020 Turkish Association of Trauma and Emergency Surgery 
Fibronectin (FN) is a glycoprotein that roles in cellular interactions and plays important functions in several processes, including cell adhesion, proliferation, migration, and differentiation. ${ }^{\left[{ }^{[}\right]} \mathrm{FN}$ is an omnipresent and necessary element of the ECM. ${ }^{[3]} \mathrm{FN}$ forms a dimer using its $\mathrm{C}$ terminal region. Each monomer arises from three types of repetitions: types I, II and III. Alternative splicing of FN may form different variants, but universally type III variants are important: Type IIIA (EIIIA located between FN repeats IIIII and IIII2) and type IIIB (EIIIB located between FN repeats III7 and III8). ${ }^{[4]}$ These variable repetitive units are one of the basic structures of the cell and are involved in different intracellular or intercellular functions, during tissue repair, and wound healing. ${ }^{[3]} \mathrm{FN}$ of plasma and tissue play differential and temporally significant functions during wound healing. Therefore, identifying a balance between the various isoforms of $\mathrm{FN}$ during tissue remodeling is essential to understanding the molecular basis of wound healing. At the site of tissue injury, FN binds to platelets and facilitates cell movement to the affected area. Expression of FN isoforms, EIIIA and EIIIB, is elevated to help tissue repair. However, it is unclear why plasma fibronectin ( $\mathrm{pFN}$ ) isoforms act simultaneously during wound healing. This complementary protein isoform function contradicts reports of pFN turnover to tissue fibronectin (tFN) but supports EIIIB complementation of EIIIA. ${ }^{[5]}$ EIIIB expression increases at the site of the wound in the tissue to help ECM formation.

Thorough literature research was performed to investigate this phenomenon and interestingly, only one study reported increased plasma EIIIB (pEIIIB) expression upon tissue injury, ${ }^{[6]}$ but several reports using different techniques found that plasma EIIIA expression levels increased upon tissue injury. ${ }^{[1,2]}$ The one study reporting increased EIIIB levels was identified with western blot analysis through a previously characterized antibody, which may not recognize the EIIIB segment directly. [7] It should be noted that the antibody failed to recognize full-length EIIIB produced by mammalian cells. Therefore, the small section on EIIIB recognized by the antibody may provide false positives, and a new validation method is required to determine $\mathrm{pEIIIB}$ levels precisely. Besides, there was no clear data about the status of EIIIB levels measured serially in the plasma and at a tissue level during skin wound healing. There are several promising studies. However, more experimental studies are needed to reduce the medical costs of chronic wounds.

Our current study elucidated a proposed correlation between $P E$ EIIIB and tEIIIB by comparing their values at various time points during wound healing. For this purpose, this study compared days $3,6,9,12$, and I5 EIIIB levels in the plasma and at a tissue level. This study employed a reproducible and quantitative method to measure both PEIIIB and tissue EIIIB (tEIIIB) levels by RT-qPCR, rather than comparing the levels by two different techniques, an ELISA for pFN determination and a semi-quantitative histological dying method for skin FN measurements, as previously reported.

\section{MATERIALS AND METHODS}

This study was carried out with five to six months old male, white New Zealand rabbits $(n=10)$, with an average of 2.7-3.0 $\mathrm{kg}$ after approval from the Animal Research Ethics Committee of our institution. Rabbits were kept in standard test cages at $22-24^{\circ} \mathrm{C}, 12 \mathrm{~h}$ light/dark cycle. After their adaptation to the laboratory, they were divided into control $(n=2)$ and study $(n=8)$ groups. All instruments (syringes, clamps, scissors, forceps, and lancets) were immersed in $0.1 \%$ diethylpyrocarbonate (DEPC) to prevent DNA and RNA contamination before withdrawing blood and taking tissue samples from the rabbits. Animals were anesthetized using an intramuscular injection of $10-20 \mathrm{mg} / \mathrm{kg}$ xylazine (Rompun 2\%, Bayer, Istanbul, Turkey) and $50 \mathrm{mg} / \mathrm{kg}$ ketamine $\mathrm{HCl}$ (Ketalar, Eczacıbaşı Warner-Lambert, Istanbul, Turkey). Intramuscular prophylactic antibiotic (50 mg/kg Ceftriaxone) and analgesic drug (4 mg/kg Carprofen) injections were administered when necessary.

In the experimental group, a circular area $2 \mathrm{~cm}$ in diameter was drawn on the dorsal region, and its boundaries were determined. A full-thickness skin defect was created by removing skin up to the panniculus carnosus at the base of the floor from the back of the animal. Blood samples, which were used to measure PEIIIB levels, were withdrawn from the marginal ear vein before defects were formed and before each biopsy was taken to measure. Tissue biopsies and blood samples were obtained from the initial wound until healing on days $3,6,9,12,15$. Additionally, in two rabbits, blood samples to measure pEIIIB levels were withdrawn from the marginal ear vein on days $3,6,9,12,15$; these were used for reference values of $p$ EIIIB level for the analyses of pEIIIB levels obtained from the experimental group.

Animals were injected with $200 \mathrm{mg} / \mathrm{kg}$ intraperitoneal sodium pentobarbital after 15 days. Tissue samples were kept in RNAlater solution and lysed with a MagNA Lyser (Roche, Indianapolis, IN). For lysed tissue samples and blood specimens, centrifugations were performed at $4^{\circ} \mathrm{C}$, and plasma samples were frozen at $-80^{\circ} \mathrm{C}$ until analysis. Total RNA was isolated and converted to cDNA (Qiagen, Germantown, MD). Primers (RT2qPCR primer) were obtained from Qiagen (Fibronectin XM_0027I6425 (Oryctolagus cuniculus fibronectin type III domain containing 3B (FNDC3B), G6PDH $X M \_002722238$ ). EIIIB levels were measured using RT-qPCR with $25 \mu \mathrm{l}$ RT2 SYBR Green Mastermix and 40 cycles. The results were analyzed at a Qiagen web portal.

\section{RESULTS}

In this study, plasma and tissue EIIIB levels from New Zealand rabbits were measured using SYBR Green RT-PCR, using G6PDH as a housekeeping gene. G6PDH was employed as a housekeeping gene. tEIIIB expression increased on day 3 and continued to increase on days 6 and 9 , reaching maximum expression on day 12 before starting to decrease. On the 


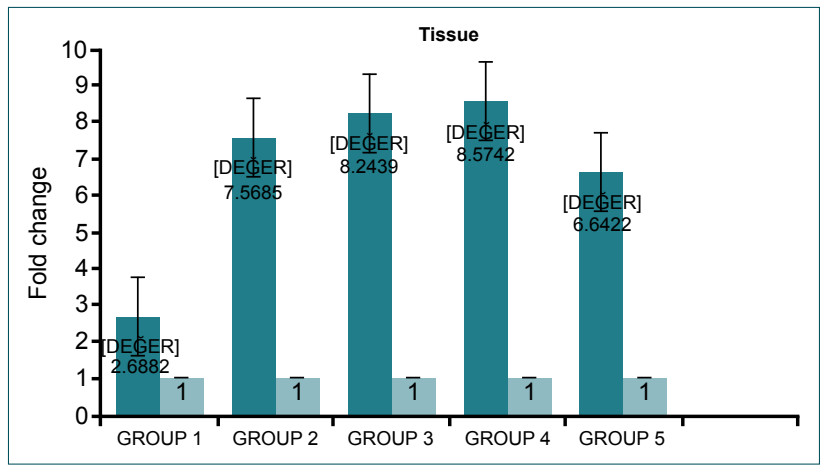

Figure 1. Fold change of tissue EIIIB expression level in skin wound tissue. Groups 1, 2, 3, 4, and 5 present days 3, 6, 9, 12, and 15 , respectively.

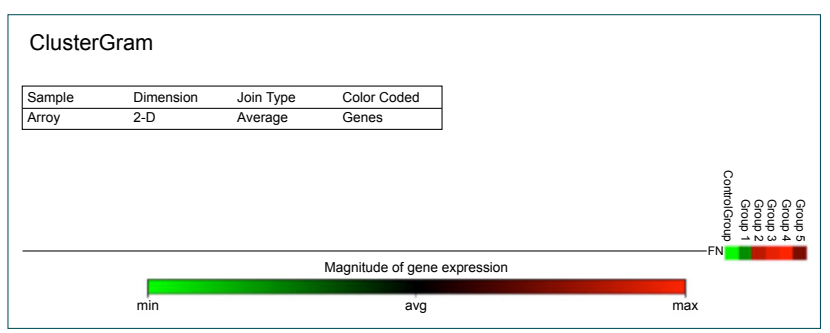

Figure 2. ClusterGram diagram. Control expression color is shown in green and a shift to red from green indicates an increase in expression levels. Groups 1, 2, 3, 4, and 5 present days 3, 6, 9, 12, and 15 , respectively.

contrary to the tissue levels, pEIIIB levels gradually decreased until day 15 when expression returned to the initial values. This suggests that early after injury, tEIIIB levels increased, while pEIIIB levels decreased. After fifteen days, tissue levels started to decrease, and PEIIIB expression increased, reaching normal levels. All wounds healed and no chronic wounds were observed. In summary, during wound healing, PEIIIB levels increased, while PEIIIB expression levels decreased simultaneously, and the results were statistically significant. Figures $\mathrm{I}-4$ show fold change values of the tissue and blood expression levels samples.

We sought to quantify levels of the EIIIB isoform through a more precise method, looking at relative fold change in PEIIIB and tEIIIB levels compared to the expression of the housekeeping gene, G6PDH. pEIIIB expression levels decreased slightly, but the expression levels returned to near initial values after fifteen days. Relative fold change of tEIIIB level was compared to the housekeeping G6PDH gene expression. tellIB expression levels increased during wound healing and then returned to initial values after two weeks. RT-qPCR can provide accurate results compared to an antibody-based method. Our experimental monitoring of EIIIB expression indicated that PEIIIB levels remain at the same level, with only a slight decrease.

\section{DISCUSSION}

To our knowledge, this was the first time the experimental monitoring of EIIIB expression measured by SYBR Green RT-

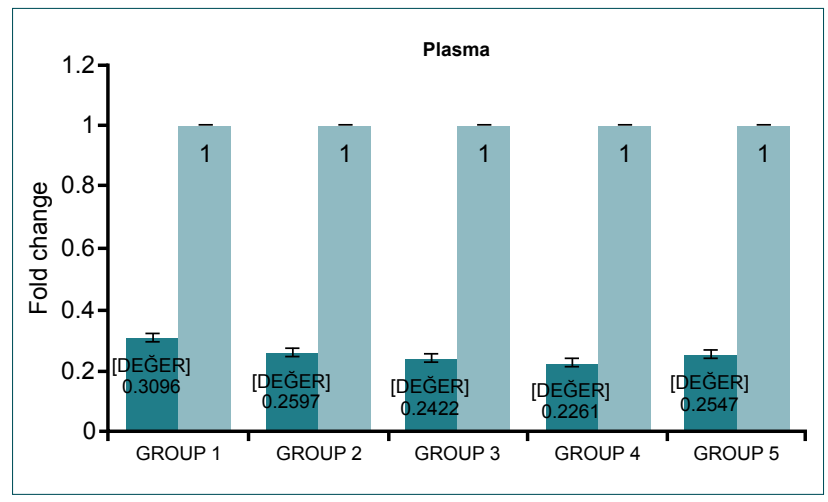

Figure 3. Fold change of pEIIIB expression level. Groups 1, 2, 3, 4, and 5 present days $3,6,9,12$, and 15 , respectively.

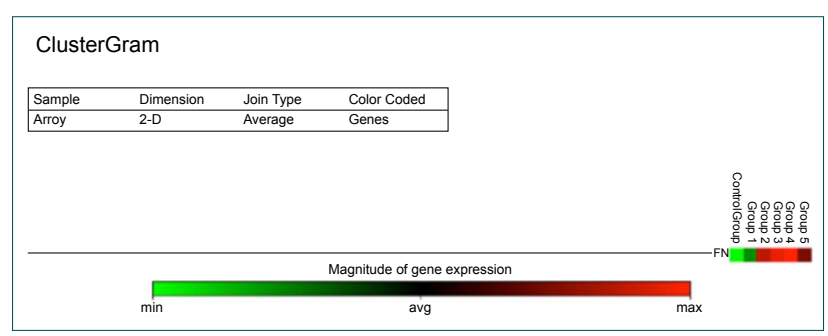

Figure 4. ClusterGram diagram. Control expression is shown in green and a shift to red from green indicates an increase in expression levels. Groups 1, 2, 3, 4, and 5 present days 3, 6, 9, 12, and 15 , respectively.

qPCR indicated that $\mathrm{PEIIIB}$ levels remained close to constant levels, albeit with a slight decrease; however, tEIIIB levels increased dramatically, which is in contrast to the antibodybased EIIIB detection. ${ }^{[6]}$ Furthermore, our results indicated that EIIIB exists in plasma, even under normal physiological conditions. tFN is a mixture of FN isoforms (EIIIB, EIIIA, V, and IIICS), and the isoforms are expressed in association with physiological or pathological conditions, such as wound healing. This correlates with our experimental results, and our study confirms that both and FN express the EIIIB isoform.

The wound is damage or an injury of the anatomical, functional integrity for any reason of healthy skin tissue. It can occur for many reasons. Based on the cause, wounds can be classified as an incision, crush, laceration, and perforation, without tissue loss, or wounds with tissue loss. ${ }^{[8,9]}$ Many biological particles, molecules, and different cell types have a part that is involved during all the wound healing phases. Besides, hemostasis, inflammation, cell proliferation, re-epithelialization, and remodeling are in succession take placed in the phases of normal wound healing. ${ }^{[9,10]}$

In the literature, there are many studies revealing new therapeutic approaches or molecular-based recovery period to overcome the difficulty and slow healing processes of chronic wounds, such as diabetic foot, decubitus, and venous leg ulcer. [9,11-15] In clinical practice, to patients with a cutaneous wound, systemic drugs as orally and parenterally can be administered; 
however, this may result in the development of several side effects limiting their long-term use. Toxic effects of systemically administered drugs and less predictable drug delivery to the damaged tissue because of possible tissue perfusion problems, there has been an important changing in the clinical tendency toward the local application of chemical agents to improve wound healing.

With a large number of local therapeutic approaches, such as platelet-rich plasma, stem cells, growth factors, fibronectin, and many molecules, have achieved promising results in developing wound healing in the experimental studies. ${ }^{[16-18]}$

FN that encoded by a single gene is a $230-270 \mathrm{kDa}$ subunits secreted as a disulfide-bounded a dimeric glycoprotein.; it also is involved in many vital functions of the cell and tissue, such as cellular adhesion, motility, hemostasis, nearly all phases of wound healing, and differentiation. ${ }^{[19,20]} \mathrm{FN}$ forms a fibrillary plexus that interacts with many components of ECM and with cell surface receptors. ${ }^{[21]}$ Two forms of $\mathrm{FN}$ have been identified: pFN, which is a soluble form, is expressed by hepatocytes into the plasma, and tFN is an insoluble form and expressed locally by fibroblasts and other many cells and deposited into ECM. It is be found in the ECM of embryonic and regenerating or wounds. ${ }^{[19,22]} \mathrm{FN}$ includes domain at three regions of the precursor mRNA: IIIA, IIIB IIICS. Although FN is encoded by a single gene, the protein exists in many variant isoforms due to alternative splicing and/or post-translational modifications that help its performance. ${ }^{[5,23]}$ pFN possesses a $V$ domain but does not have EIIIA and EIIIB domains. ${ }^{[22]}$ It has been reported that only very low levels of cellular FN with EIIIA and/or EIIIB domains circulate in blood plasma, and further, levels increase after major trauma. ${ }^{[1,24]}$ No comparison between tissue and PEIIIB expression levels had been investigated before this study. Further, these results were found by employing an antibody to detect the EIIIB domain. The antibody has been shown to fail in recognizing full-length EllIB produced by mammalian cells. Our experimental set up was based on quantification of the EIIIB isoform through a more precise method. RT-qPCR can provide more accurate results compared to the antibody-based method.

FN encouragement the re-epithelialization of the cutaneous wound by stimulating fibroblasts and epidermal cells. ${ }^{[19,25]}$ The wound bad end granulation tissue through which keratinocytes migrate have been found to be rich in pFN, while other basement membrane proteins, laminin, and type IV collagen were found to be absent from beneath the migratory edge of the epidermis. ${ }^{[25,26]} \mathrm{FN}$ isoform turnover or splicing is similar to the constitutive and inducible HSP biochemical complementation process. Therefore, at initial wound formation and during wound healing, cells are exposed to stress, and different isoforms of $\mathrm{FN}$ may form different functions. pFN is known to be effective in many stages of wound healing, including hemostasis, infection control, the formation of granulation tissue, and epithelialization. ${ }^{[27,28]}$ In conclusion, tissue repair may employ ElIIB for cell migration and proliferation, which is an essential part of healing skin wounds for inward migration of epidermal cells from the edges. Thus, this study shows an essential role of EIIIB in accelerating wound healing.

It has been previously reported that topical administration of pFN in chronic wounds positively affects wound healing by affecting fibroblast activity, transforming growth factor-ßI. [9] Recently, it has been reported that the application of the chimeric fibronectin protein to diabetic wounds and corneal epithelial wounds of topical fibronectin-derived peptides accelerates wound healing in the experimental studies. ${ }^{[18,29,30]}$ In this study, both isoforms were detected in the wound, and the healing process was identical to early embryogenesis. Thus, FN splicing during wound healing may be employed during wound healing to create proper forms of FN for tissue repair.

A study conducted on spondyloarthropathy patients, comparing rheumatoid arthritis patients and healthy volunteers, indicated that a difference between pFN levels could not be connected to systemic inflammation alone. Rather, the local turnover of EIIIA and EIIIB FN isoforms contributed to the inflamed tissue. Further, the EIIIB FN isoform is thought to be involved in the musculoskeletal inflammatory duration of spondyloarthropathy. ${ }^{[31]}$ This study supports our data on EIIIB levels.

Kwon et al. ${ }^{[19,32]}$ conducted the studies investigating pFN administered intravenously or applied topically immediately after wounding enhances incisional wound healing in a rat model. They found that single administration and application of pFN increased wound healing parameters. They suggested that this may be related to the increased amount of hydroxyproline in the healing wound. Their findings supported that sustaining adequate levels of pFN by administering intravenous $\mathrm{pFN}$ contributed to the quality of wound healing.

As mentioned above, $\mathrm{FN}$ is used in experimental studies to examine its role in the wound healing process. Overall, FN has the potential to be a component of new drugs to improve wound healing. There is not enough information about the place of isoforms of $\mathrm{FN}$ in different phases of the wound healing process. As a limitation, in this study, other forms of FN were not included in the gene expression trials. In conclusion, the results of our study support the use of EIIIB isoform measured by SYBR Green RT-PCR as the component of the PEIIIB and $t E I I I B$ in a full-thickness cutaneous wound model of the rabbit. Overall, the findings of this study have the potential to lead the development of fibronectin-based biomarkers that can be used to monitor treatment success during the followup of wound healing procedures in clinical practice. Based on this preliminary study, a new fibronectin dependent wound healing scale can be investigated. By conducting many experimental studies in the future, this method, which is more re- 
liable, can be used to look for fibronectin levels and provide guiding measurements on the timing of surgery in difficult-toheal wounds such as diabetic foot and pressure sores. Further studies can shed light on whether EIIIB has merit to become a drug candidate for patients with wound healing problems.

Ethics Committee Approval: Approved by the local ethics committee.

Peer-review: Internally peer-reviewed.

Authorship Contributions: Concept: N.K.Ö., U.Z., K.A.C., Y.T., S.Y.; Design: N.K.Ö., U.Z., K.A.C., Y.T., S.Y.; Supervision: N.K.Ö., Y.T., S.Y.; Fundings: N.K.Ö., U.Z., K.A.C.; Materials: N.K.Ö., U.Z., K.A.C.; Data: N.K.Ö., U.Z., K.A.C., Y.T., S.Y.; Analysis: N.K.Ö., U.Z., K.A.C., Y.T., S.Y.; Literature search: N.K.Ö., U.Z., K.A.C., Y.T., S.Y.; Writing: N.K.Ö., U.Z., K.A.C., Y.T., S.Y.; Critical revision: N.K.Ö., Y.T., S.Y.

Conflict of Interest: None declared.

Financial Disclosure: This work has been supported by the Scientific Research Project Fund of our University.

\section{REFERENCES}

1. Maxson S, Lopez EA, Yoo D, Danilkovitch-Miagkova A, Leroux MA. Concise review: role of mesenchymal stem cells in wound repair. Stem Cells Transl Med 2012;1:142-9. [CrossRef]

2. Singer AJ, Clark RA. Cutaneous wound healing. N Engl J Med 1999;341:738-46. [CrossRef]

3. Lenselink EA. Role of fibronectin in normal wound healing. Int Wound J 2015;12:313-6. [CrossRef]

4. Pankov R, Yamada KM. Fibronectin at a glance. J Cell Sci 2002;115:3861-3. [CrossRef]

5. To WS, Midwood KS. Plasma and cellular fibronectin: distinct and independent functions during tissue repair. Fibrogenesis Tissue Repair 2011;4:21. [CrossRef]

6. Peters JH, Loredo GA, Chen G, Maunder R, Hahn TJ, Willits NH, et al. Plasma levels of fibronectin bearing the alternatively spliced EIIIB segment are increased after major trauma.J Lab Clin Med 2003;141:401-10.

7. Peters JH, Trevithick JE, Johnson P, Hynes RO. Expression of the alternatively spliced EIIIB segment of fibronectin. Cell Adhes Commun 1995;3:67-89. [CrossRef]

8. Paul W, Sharma CP. Chitosan and alginate wound dressings: A short review. Trends Biomater Artificial Organs 2004;18:18-23. [CrossRef]

9. Al-Rawaf HA, Gabr SA, Alghadir AH. Circulating Hypoxia Responsive microRNAs (HRMs) and Wound Healing Potentials of Green Tea in Diabetic and Nondiabetic Rat Models. Evid Based Complement Alternat Med 2019;2019:9019253. [CrossRef]

10. Clark RA. Fibrin and wound healing. Ann N Y Acad Sci 2001;936:355-67. [CrossRef]

11. Takeo M, Lee W, Ito M. Wound healing and skin regeneration. Cold Spring Harb Perspect Med 2015;5:a023267. [CrossRef]

12. Kallis PJ, Friedman AJ. Collagen Powder in Wound Healing. J Drugs Dermatol 2018;17:403-8.

13. Woodley DT. Distinct Fibroblasts in the Papillary and Reticular Dermis: Implications for Wound Healing. Dermatol Clin 2017;35:95-100.
14. Kim H, Kong WH, Seong KXung DK, Jeong H, Kim JK, et al. Hyaluronate-Epidermal Growth Factor Conjugate for Skinuwd Healing and Regeneration. Biomacromolecules 2016;17:3694-705.

15. Sahin Inan ZD, Unver Saraydin S. Investigation of the wound healing effects of chitosan on FGFR3 and VEGF immunlocalization in experimentally diabetic rats. Int J Bio Materials Res 2013;1:1-8. [CrossRef]

16. Johnson MB, Pang B, Gardner DJ, Niknam-Benia S, Soundarajan V, Bramos A, et al. Topical Fibronectin Improves Wound Healing of Irradi-ated Skin. Sci Rep 2017;7:3876. [CrossRef]

17. Whittam AJ, Maan ZN, Duscher D, W ong VW, Barrera JA, Januszyk $\mathrm{M}$, et al. Challenges and Opportunities in Drug Delivery for $\mathrm{W}$ ound Heal-ing. Adv Wound Care (New Rochelle) 2016;5:79-88. [CrossRef]

18. Hamed S, Ullmann Y, Egozi D, Daod E, Hellou E, Ashkar M, et al. Fibronectin potentiates topical erythropoietin-induced wound repair in diabetic mice. J Invest Dermatol 2011;131:1365-74. [CrossRef]

19. Kwon AH, Qiu Z, Hiraon Y. Effect of plasma fibronectin on the incisional wound healing in rats. Surgery 2007;141:254-61. [CrossRef]

20. Tomasini-Johansson BR, Zbyszynski PW, Toraason I, Peters DM, Kwon GS. PEGylated pUR4/FUD peptide inhibitor of fibronectin fibrillogenesis decreases fibrosis in murine Unilateral Ureteral Obstruction model of kidney disease. PLoS One 2018;13:e0205360. [CrossRef]

21. Mao Y, Schwarzbauer JE. Fibronectin fibrillogenesis, a cell-mediated matrix assembly process. Matrix Biol 2005;24:389-99. [CrossRef]

22. Magnusson MK, Mosher DF. Fibronectin: structure, assembly, and cardiovascular implications. Arterioscler Thromb Vasc Biol 1998;18:1363-70.

23. Kornblihtt AR, Umezawa K, Vibe-Pedersen K, Baralle FE. Primary structure of human fibronectin: differential splicing may generate at least 10 polypeptides from a single gene. EMBO J 1985;4:1755-9. [CrossRef]

24. Jarnagin WR, Rockey DC, Koteliansky VE, Wang SS, Bissell DM. Expression of variant fibronectins in wound healing: cellular source and biological activity of the EIIIA segment in rat hepatic fibrogenesis. J Cell Biol 1994;127:2037-48. [CrossRef]

25. Takashima A, Billingham RE, Grinnell F. Activation of rabbit keratinocyte fibronectin receptor function in vivo during wound healing. J Invest Dermatol 1986;86:585-90. [CrossRef]

26. Ongenae KC, Phillips TJ, Park HY, Level of fibronectin mRNA is markedly increased in human chronic wounds. Dermatol Surg 2000;26:447-51. [CrossRef]

27. Sazuka M, Isemura M, Isemura S. Interaction between the carboxyl-terminal heparin-binding domain of fibronectin and (-)-epigallocatechin gallate. Biosci Biotechnol Biochem 1998;62:1031-2. [CrossRef]

28. Dooley A, Shi-Wen X, Aden N, Tranah T, Desai N, Denton C, et al. Modulation of collagen type I, fibronectin and dermal fibroblast function and activity, in systemic sclerosis by the antioxidant epigallocatechin-3-gallate. Rheumatology (Oxford) 2010;49:2024-36. [CrossRef]

29. Hocking DC, Brennan JR, Raeman CH. A Small Chimeric Fibronectin Fragment Accelerates Dermal Wound Repair in Diabetic Mice. Adv Wound Care (New Rochelle) 2016;5:495-506. [CrossRef]

30. Morishige N, Uemura A, Morita Y, Nishida T. Promotion of Corneal Epithelial Wound Healing in Diabetic Rats by the Fibronectin-Derived Peptide PHSRN. Cornea 2017;36:1544-8. [CrossRef]

31. Claudepierre P, Allanore Y, Belec L, Larget-Piet B, Zardi L, Chevalier $\mathrm{X}$. Increased Ed-B fibronectin plasma levels in spondyloarthropathies: comparison with rheumatoid arthritis patients and a healthy population. Rheumatology (Oxford) 1999;38:1099-103. [CrossRef]

32. Kwon AH, Qiu Z, Hirao Y. Topical application of plasma fibronectin in full-thickness skin wound healing in rats. Exp Biol Med (Maywood) 2007;232:935-41. 
DENEYSEL ÇALIŞMA - ÖZET

Tavşan yara modelinde RT-PCR yöntemi ile seri olarak ölçülen plazma ve doku fibronektin EIIIB splice değerlerinin ölçümleri

Dr. Neşe Kurt Özkaya, ${ }^{1}$ Dr. Umut Zereyak, ${ }^{2}$ Dr. Kübra Açıkalın Coşkun, ${ }^{3}$ Dr. Yusuf Tutar, ${ }^{4}$ Dr. Sarper Yılmaz ${ }^{5}$

${ }^{1}$ Sivas Cumhuriyet Üniversitesi Tıp Fakültesi, Plastik Rekonstrüktif Estetik Cerrahi Anabilim Dalı, Sivas

${ }^{2}$ Özel Medicana Hastanesi, Plastik Rekonstrüktif Estetik Cerrahi Birimi, Sivas

${ }^{3}$ Sivas Cumhuriyet Üniversitesi Tıp Fakültesi, Araştırma Merkezi, Sivas

${ }^{4}$ Sağlık Bilimleri Üniversitesi, Eczacılık Fakültesi ve Moleküler Tıp Programı, İstanbul

${ }^{5}$ Ufuk Üniversitesi Tıp Fakültesi, Plastik Rekonstrüktif Estetik Cerrahi Anabilim Dalı, Ankara

AMAÇ: Fibronektin (FN), hücre dışı matriksin vazgeçilmez bir parçasıdır. Rejenerasyon veya yara iyileşmesi sırasında FN'nin plazma formu, geçici bir fibrin-FN matrisi oluşturmak için fibrin pıhtılarına dahil olur ve ayrıca lokal olarak sentezlenen hücresel FN, yaralı dokuyu rejenere etmek için pıhtıya göç eder. Bu çalışmada tavşanlarda deneysel yara iyileşme modelinde yara dokusu EIIIB ve plazma ElIIB ekspresyon düzeylerini incelemeyi amaçladık. GEREÇ VE YÖNTEM: Plazma ve doku EIIIB ekspresyon düzeyleri, tavşanların kutanöz yara modelinde RT-qPCR ile seri olarak ölçüldü.

BULGULAR: Doku FN ekspresyonu 3. günden başlayarak arttı, 6. ve 9. günlerde artmaya devam etti, azalmaya başlamadan önce I2. günde maksimum ekspresyona ulaştı. Doku seviyelerinin aksine, plazma FN seviyeleri ekspresyon başlangıç değerlerine döndüğünde I5. güne kadar kademeli olarak azaldı.

TARTIŞMA: Sonuç olarak, mevcut çalışmanın bulguları, yara iyileşmesi sırasında doku EllIB ekspresyon seviyesinin arttığını desteklemektedir; plazma EIIIB ekspresyon seviyesi minimum düzeyde azalır. Bu, plazma FN'nin geçici olarak ECM oluşumuna yardımcı olduğu raporların aksine değerlerdir. Bu nedenle verilerimiz, yara iyileşme sürecini hızlandırmada EllıB'nin doku düzeyinde önemli bir rol oynadığını göstermektedir. Ayrıca, deneyde kullandığımı ölçme yöntemimiz olan RT-qPCR yöntemi, antikor bazlı yöntemlere kıyasla daha doğru ve kesin sonuçlar sağlayabilir.

Anahtar sözcükler: Fibronektin; plazma fibronektin ElIIB; RT-qPCR; tavşan; yara iyileşmesi.

Ulus Travma Acil Cerrahi Derg 2020;26(4):497-502 doi: 10.14744/tjtes.2020.25260 